\title{
Journal of Applied Economics and Business Studies (JAEBS)
}

\author{
Journal homepage: https://jaebs.com \\ ISSN (Print): 2523-2614 \\ ISSN (Online) 2663-693X
}

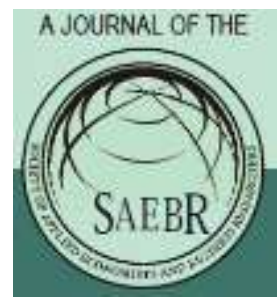

\section{A cointegration analysis between macroeconomic variables and fiscal deficit in Pakistan}

Mian Nasir Uddin ${ }^{1}$, Muhammad Tariq ${ }^{2 *}$ \& Saleem Khan $^{3}$

${ }^{1}$ MS Scholar, Department of Economics, Abdul Wali Khan University Mardan.

2,3 Assistant Professor, Department of Economics, Abdul Wali Khan University Mardan

\begin{abstract}
This paper estimates the short and long run association between selected macroeconomic variables and fiscal deficit in Pakistan for the period of 1985 to 2016. Macroeconomic variables such as exports, exchange rate, GDP per capita, inflation, gross capital formation have strong implications for the fiscal deficit. This study checks the data for stationarity using the Augmented Dickey Fuller test. Johansen Co-integration test and Vector Error Correction Method are used to investigate both the short and long run relationships. Results indicated the existence of both short run and long run relationship between the macroeconomic variables and fiscal deficit. The findings of the study revealed that exports, exchange rate, GDP per capita, inflation, gross capital formation are important determinants of fiscal deficit in Pakistan. The study suggested that the government may focus on these factors to overcome fiscal deficit in Pakistan.
\end{abstract}

Keywords

Fiscal Deficit, Johansen

Cointegration test, Vector Error Correction

Method

JEL

Classification B22, E6, E62, E63, F62

Copyright (C) 2018 SAEBR - All rights reserved

\section{Introduction}

Fiscal deficit arises when the government's expenditures are more than the government's revenues. Fiscal deficit has remained a major issue in both developed and developing countries. Payments needed for fiscal imbalances create variations in the interest rate and increase government loans. Fiscal imbalances in underdeveloped economies are considered as a soaring problem (Anwar \& Ahmad, 2012). One of the main reasons of fiscal deficit is an increase in public spending with constant or decreasing collection of revenues through taxes and other sources. Reduction in fiscal deficit can help in accelerating the development (Romer, 1986). Reduction in fiscal deficit can have negative effect on social development as many underdeveloped economies in order to minimize fiscal deficit, they reduce investments in social sectors such as health, education, and infrastructure. Others reduce it by increasing the tax rate. Most economists agree that sustained deficits can damage a 
country's economy, and high fiscal deficit creates major challenges for middle-income economies (Agenor \& Montiel, 1999). Furthermore, rising government spending may be undertaken to boost economic growth and wellbeing of the individuals (Peacock \&Wiseman, 1961).

Pakistan has been consistently facing the problem of increasing fiscal deficit. High fiscal deficit in the economy is a consequence of high inflation as well as low growth (Chaudhary $\&$ Abe, 1999). Figure 1 exhibits the fiscal deficit pattern of Pakistan and indicates a widening gap over time (Pakistan Economics Survey, 2016-17).

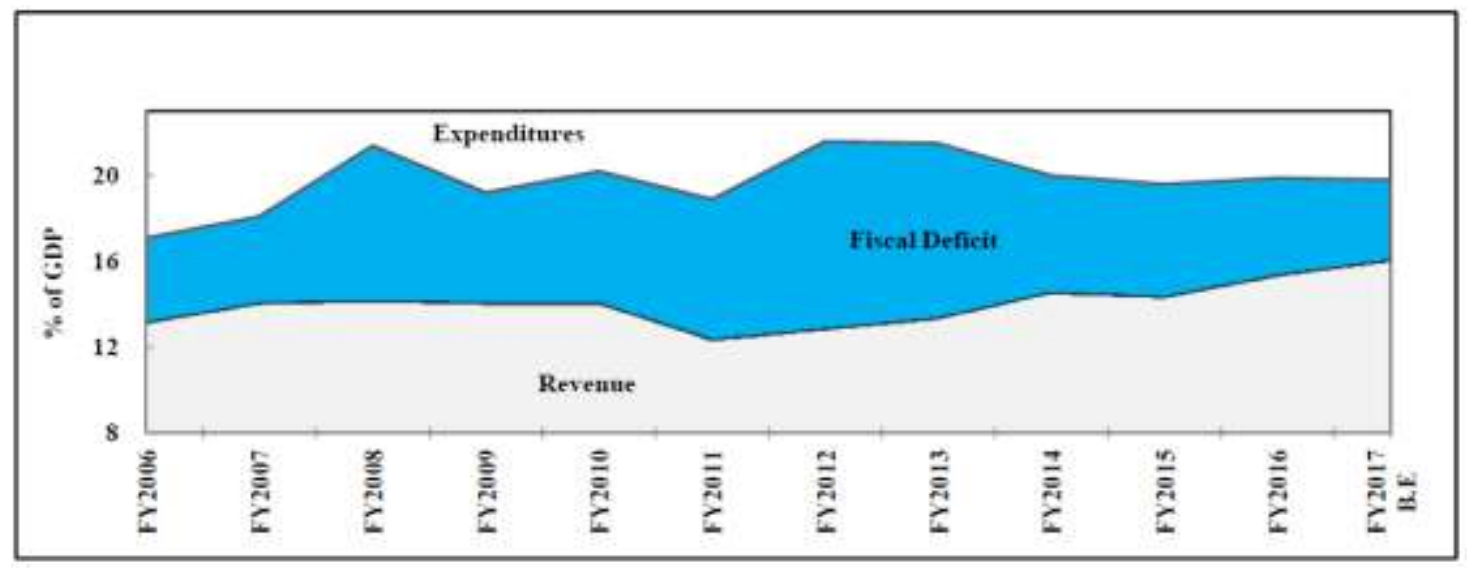

Figure 1: Expenditure and Revenue Gap (\%age of GDP)

Pakistan has high population of about 193.2 million in 2016 (WDI, 2018). Also, it has small level of GDP per capita amounting to 1641 US dollars (GOP, 2017-18). Pakistan's budget deficit in the last two decades has been 5.4\% to $8.7 \%$ of its GDP. Pakistan's budget deficit as percent of GDP has been respectively 6\%, 7.6\% and 6.4\% in 1970's, 1980's, and 1990 's. Despite increasing budget deficit, there has not been many tax reforms to generate more revenue for the government. Maintaining a reasonable fiscal deficit level requires a balance between expenditure and revenues. However, due to lack of attention and poor governance in the taxation system such as many exemptions, and poor collection system has been affecting the Pakistan's economy. It has been recognized that there has been an association between GDP per capita, inflation, exchange rate, exports and gross capital formation and fiscal deficit. Therefore, this study explores the factors affecting the fiscal deficit of Pakistan and test if short-run and long-run relationships exist between macroeconomic variables and fiscal deficit.

\section{Literature review}

Agha \& Khan (2006) investigated the long run association between inflation and fiscal deficit in Pakistan using monthly time series data from 1973-2003. They used Johansen cointegration test and vector error correction models (VECM) for testing the relationship. 
They found that inflation was associated with fiscal deficit in the long run. Also, the VECM model indicated that inflation is affected by the public's borrowings from banks when fiscal deficit is financed. Epaphra (2017) found that the exchange rate and real GDP had a negative role on budget deficit while budget deficit was positively related to money supply, inflation and interest rate in Tanzania. Usman and Adebisi (2017) also investigated the factors responsible for widening the gap between Nigerian's government revenue and expenditures.

Uppal (2011) stated that Pakistan's political process, institutional condition, and budget processes influences the fiscal budget and that the fiscal deficit can be improved by introducing better discipline, institutional checks \& balances and better market discipline. Better governance and development of political institutions can play a long-term improvement in the fiscal deficit. Furthermore, Javid et al. (2011) studied the budget deficit of South Asia and ASEAN countries using the dynamic panel method. They found that high inflation and high budget to GDP ratio had a positive effect on budget deficit whereas better political situation, growth and social development negative effect on deficits. Furthermore, it is also found that corruption and mismanagement were contributing to high budget deficit.

Anwar \& Ahmad (2012) examined the short and long run association between deficit and factors such as democracy, economic growth of Pakistan. They found that government size had positive impact on the budget deficit. Furthermore, democracy was not found to have any impact on the budget deficit of Pakistan. Also, Brima and Pearce (2015) investigated the association of financial deficit with selected macroeconomic variables using Johansen's test of co-integration, vector error correction model and the Granger causality in Sierra Leone for the period from 1980 to 2014. They found that exchange rate, GDP and supply of money had an inverse association with the deficit while interest rate and inflation had a positive relationship with the budget deficit.

Torayeh (2015) employing the auto-regressive distributed lag (ARDL) estimated the factors for deficit in Egypt using time series data from 1985 to 2013. They found that the interest payments and people income increase the Egypt deficits. Further, these payments eat away a big chunk of the tax revenues. They suggested that subsidies and interest payments may be curtailed to control the budget deficit. Further, tax reforms are also needed to improve the revenue. Safdar and Padda (2017) also investigated the impact of institutional quality on budget deficit utilizing time series data from 1984 to 2014. They found that weak institutions cause high budget deficit due to mismanagement and leakages in the economy. Further, they discovered that open trade and inflation had a positive effect on the financial deficit. Real gross domestic product per capita was not found to have a significant effect on budget deficit. Mismanagement, fraud, corruption, weak rules and regulation also cause the deficit. They suggested that policymakers should pay attention to improve institution's quality to improve the budget deficit. 


\section{Research methods}

This section discusses the data and the empirical model of the study. Since this study is an empirical in nature, data pattern shall show us the relationship between the fiscal deficit and macroeconomic variables. Therefore, we focus on data and empirical model. The study uses the data from 1985 to 2016. All the data about different variables have been collected from Economic Surveys of Pakistan and World Development Indicators of World Bank.

This study uses Jagirani, et al. (2016) for examining the relationship between the dependent variable and independent variables of the study given as follows:

$$
F D=\beta_{0}+\beta_{1} E X+\beta_{2} E X C+\beta_{3} G D P P C+\beta_{4} G C F+\beta_{5} I N F+\varepsilon
$$

where FD is the fiscal deficit (\% of GDP), and EX for Exports ((\% of GDP), EXC for Exchange Rate (Rs. /US\$), GDPPC for Gross Domestic Product Per Capita (Rs.), GCF for Gross Capital Formation ((\% of GDP) and INF for inflation (\%). Moreover, $\beta_{0}$ is the intercept and $\beta_{1}, \beta_{2}, \beta_{3}, \beta_{4}$, and $\beta_{5}$ are the parameters to be estimated and $\varepsilon$ is the error term.

When variables are non-stationary, then we have the problem of spurious results (Juseof, et al. 2011). Therefore, the data is tested for stationarity using the Augmented Dickey Fuller (ADF) test given below:

$$
\Delta y=\alpha_{0+} \alpha_{1} y_{t-1} \sum_{i=1}^{p} \alpha_{\mathrm{i}} \Delta \mathrm{y}_{\mathrm{t}-1}+\varepsilon_{\mathrm{t}}
$$

Johansen cointegration test shall be used to test for the cointegration (whether there is a short and long run association). Cointegration approach is applicable when the data is integration of order one (I(1)). Cointegrating equations can be tested through trace statistics ( $\lambda$ trace) and the maximum Eigen statistics $(\lambda \max )$. Furthermore, vector error correction model (VECM) is used when variables are cointegrated in the long run otherwise one can use the vector autoregressive model for the variable. Finally, Wald test is used to find out the existence of short-run relationships.

\section{Results and discussion}

\subsection{Stationarity Test}

We use the time series data and it is important to check the data for stationarity. We use the ADF test to check for unit root. The results of unit root or ADF test are listed in table 1 as follows.

Table 1: Augmented Dickey-Fuller (ADF) Test Results

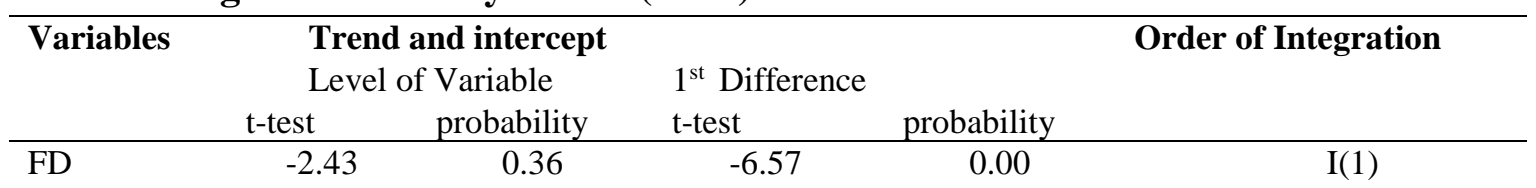


Journal of Applied Economics and Business Studies, Volume. 2, Issue 1 (2018) 37-46 https://doi.org/10.34260/jaebs.214

\begin{tabular}{lccccc}
\hline EX & -2.23 & 0.46 & -4.86 & 0.00 & $\mathrm{I}(1)$ \\
EXC & 1.72 & 0.99 & -4.40 & 0.01 & $\mathrm{I}(1)$ \\
GCF & -2.52 & 0.32 & -5.50 & 0.00 & $\mathrm{I}(1)$ \\
GDPPC & -2.30 & 0.42 & -6.91 & 0.00 & $\mathrm{I}(1)$ \\
INF & -2.30 & 0.42 & -6.91 & 0.00 & $\mathrm{I}(1)$ \\
\hline
\end{tabular}

Source: own Estimation.

The ADF test results in table 1 shows that all variables are non-stationary at level and they become stationary after at $1^{\text {st }}$ difference. When all variables are $\mathrm{I}(1)$, then we have cointegration test to check for the linear relationship between the variables (Brima \& Pearce, 2015). Johansen Cointegration test shall be used to investigate the long run relationship; however, it is important to determine the lag length using the Akaike Information Criterion (AIC).

\subsection{Determination of the Optimal Lag Selection}

In order to run the Johansen's test of co-movement and the VECM, the optimal lag selection criteria w adopted to determined the lag length that would be used in estimation. Various lag length criteria such as LogL, sequential modified LR test statistic, final prediction error (FPE), Schwarz information criterion (SC), Akaike information criterion (AIC), and Hannan Quinn information criterion (HQ) have been used to determine the optimal lag length indicated by *. It is indicated in table 2 that the optimal lag length based on the majority of criteria is two.

Table 2: Lag length Criteria

\begin{tabular}{ccccccc}
\hline Lag & LogL & LR & FPE & AIC & SC & HQ \\
\hline 0 & -690.26 & NA & $5.81 \mathrm{e}+12$ & 46.42 & 46.69 & 46.51 \\
1 & -520.98 & 259.55 & $8.47 \mathrm{e}+08$ & 37.53 & $39.49^{*}$ & 38.16 \\
2 & -466.26 & $62.04^{*}$ & $3.33 \mathrm{e}+08^{*}$ & $36.28^{*}$ & 39.93 & $37.45^{*}$ \\
\hline
\end{tabular}

Source: own Estimation.

\subsection{Co-integration of variables}

To check the co-integration between the variables, Johansen's co-integration test of trace statistics ( $\lambda$ trace) and the maximum eigen statistics $(\lambda \max )$ were used. The results of the Johansen's co-integration test are presented in tables 3 and 4. 
Table 3: Unrestricted Co-integration Rank Test (Trace)

\begin{tabular}{lcccc}
\hline Hypothesized equations & Eigenvalues & Trace Statistic & Critical Value & Prob \\
\hline No & 0.93 & 186.19 & 95.75 & 0.00 \\
At 1 & 0.81 & 107.42 & 69.81 & 0.00 \\
At 2 & 0.71 & 59.15 & 47.85 & 0.00 \\
At 3 & 0.35 & 22.29 & 29.79 & 0.28 \\
At 4 & 0.26 & 9.65 & 15.49 & 0.31 \\
At 5 & 0.02 & 0.70 & 3.84 & 0.40 \\
\hline
\end{tabular}

Source: own Estimation.

Table 4: Unrestricted Co integration rank test (maximum eigenvalue)

\begin{tabular}{lcccc}
\hline Hypothesized equations & Eigenvalues & Trace Statistic & Critical Value & Prob \\
\hline None & 0.93 & 78.76 & 40.07 & 0.0 \\
At 1 & 0.81 & 48.27 & 33.87 & 0.00 \\
At 2 & 0.71 & 36.85 & 27.58 & 0.00 \\
At 3 & 0.35 & 12.64 & 21.13 & 0.48 \\
At 4 & 0.26 & 8.94 & 14.26 & 0.29 \\
At 5 & 0.02 & 0.70 & 3.84 & 0.40 \\
\hline
\end{tabular}

Source: own Estimation.

Results of both trace and maximum Eigen values indicate three co-integrating equations at $5 \%$ significance level. When variables are found cointegrating at $\mathrm{I}(1)$, then we use both ( $\lambda$ Trace) and ( $\lambda$ Max) values in estimating the Vector Error Correction Model (VECM).

\subsection{Vector error correction model (VECM)}

The results of Vector error correction model (VECM) are presented in table 5. It shows that there are long-run relationships between fiscal deficit and selected macroeconomics variables. This test also indicates the speed of adjustment from disequilibrium to the equilibrium. Coefficient values of all the Coint equations 1,2 and 3 are negative and statistically significant indicating a trend towards equilibrium adjustment.

Table-5: Vector error correction model (VECM)

\begin{tabular}{lllll}
\hline Variables & Coefficient & S. Error & t-value & p-value \\
\hline CointEq1 & -2.000001 & 0.270230 & -7.509379 & 0.0000 \\
CointEq2 & -0.610761 & 0.257857 & -2.368602 & 0.0340 \\
CointEq3 & -0.228549 & 0.062938 & -3.631337 & 0.0030 \\
D(FD(-1) & 0.538951 & 0.193443 & 2.786105 & 0.0154 \\
D(FD(-2)) & 0.409828 & 0.171841 & 2.384927 & 0.0330 \\
D(EX(-1)) & -0.577595 & 0.155129 & 3.723324 & 0.0026 \\
D(EX(-2)) & 0.095028 & 0.177754 & 0.534606 & 0.6019 \\
D(EXC(-1)) & 0.130318 & 0.142519 & 0.914392 & 0.3772 \\
D(EXC(-2)) & -0.039340 & 0.086768 & -0.453388 & 0.6577 \\
D(GCF(-1)) & 0.436087 & 0.287419 & 1.517255 & 0.1531 \\
D(GCF(-2)) & 0.272770 & 0.261824 & 1.041807 & 0.3165 \\
D(GDPPC(-1)) & -0.000197 & $7.89 E-05$ & 2.491265 & 0.0270 \\
D(GDPPC(-2)) & $-1.61 E-05$ & $7.31 E-05$ & 0.219743 & 0.8295 \\
D(INF(-1)) & 0.487991 & 0.152115 & -3.208034 & 0.0069 \\
D(INF(-2)) & 0.317594 & 0.074637 & -4.255179 & 0.0009 \\
C & -1.181520 & 1.217501 & -0.970447 & 0.3495 \\
R & 0.905955 & Adjusted R & & 0.7974 \\
\hline
\end{tabular}

Source: own Estimation. 
Similarly, Wald test is used to check for the pair wise relations of the fiscal deficit with the selected macroeconomic variables given in table 6. Wald test indicates that there is no short-run relationship of GCF and EXC with the fiscal deficit while EX, GDPPC, and INF have a statistically significant short run relationship with the fiscal deficit.

Table 6: Wald Test Results

\begin{tabular}{lccc}
\hline \multicolumn{1}{c}{ Variable } & Chi -square & D.F & P-value \\
\hline EX-FD & 13.87492 & 2 & 0.00 \\
GCF - FD & 2.358778 & 2 & 0.30 \\
GDPPC - FD & 7.190731 & 2 & 0.02 \\
INF - FD & 18.24464 & 2 & 0.00 \\
EXC - FD & 2.919783 & 2 & 0.23 \\
\hline
\end{tabular}

Source: own Estimation.

\subsection{Diagnostic and other stability tests of the model}

Once the model is estimated, it is important to check the model for autocorrelation and heteroskedasticity problems prior to using it for prediction or policy analysis. The results of the autocorrelation and heteroskedasticity are given respectively in table 7 and 8 . Table 7 and 8 indicate that based on the Breusch-Godfrey serial correlation LM test, we conclude that the model does not have a serial correlation heteroskedasticity problems.

Table 7: Breusch-Godfrey serial correlation LM test results

\begin{tabular}{llll} 
F-stat & 1.89 & Prob. F(2,11) & 0.19 \\
\hline Obs*R-squared & 7.432 & Prob. Chi-Square(2) & 0.02
\end{tabular}

Source: own Estimation.

Table 9: Heteroskedasticity Test: Breusch-Pagan-Godfrey

\begin{tabular}{llll}
\hline F-statistic & 1.089610 & Prob. F(18,10) & 0.46 \\
\hline Obs*R-squared & 19.20700 & Prob. Chi-Square(18) & 0.37 \\
\hline Scaled explained SS & 4.013151 & Prob. Chi-Square(18) & 0.99 \\
\hline
\end{tabular}

Source: own Estimation.

Finally, the data is checked for the normality and for that Jarque-Bera test is used and the results are provided in figure 3. The residual of this model is distributed normally because the p-value of the Jarque-Bera is more than $5 \%$ and we accept the null hypothesis of normality. 

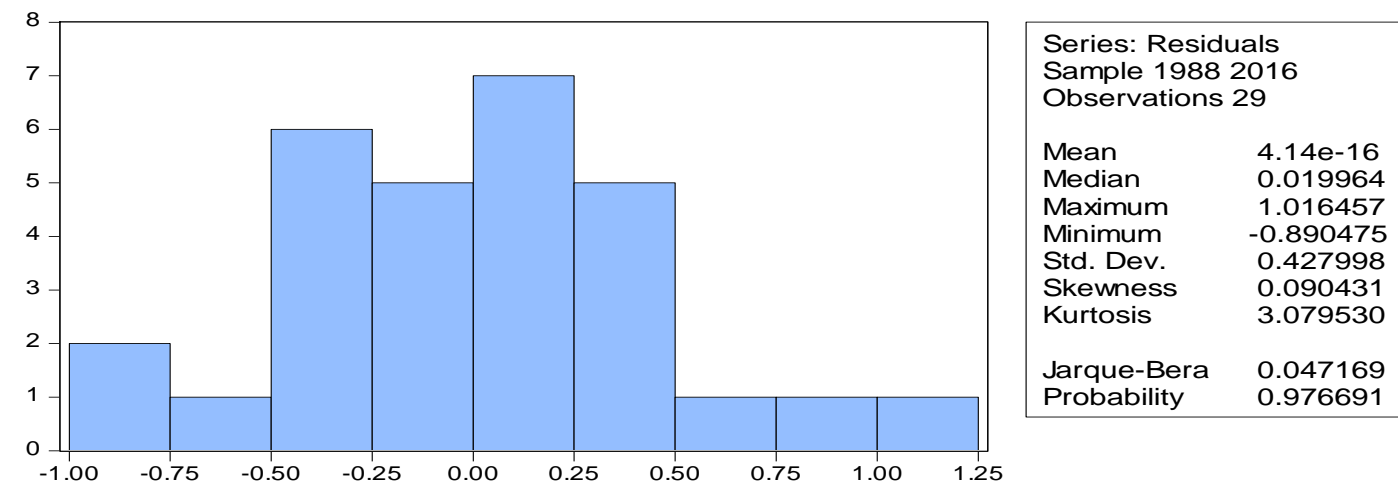

Figure 3: Normality assessment

The stability test is another important part of the diagnostics tests which is estimated by CUSUM test. CUSUM technique is shown in the figure 4 below. CUSUM test indicates that the model is stable with the $5 \%$ level of significance as the blue line in the above figure is within both critical lines i.e. dash lines.

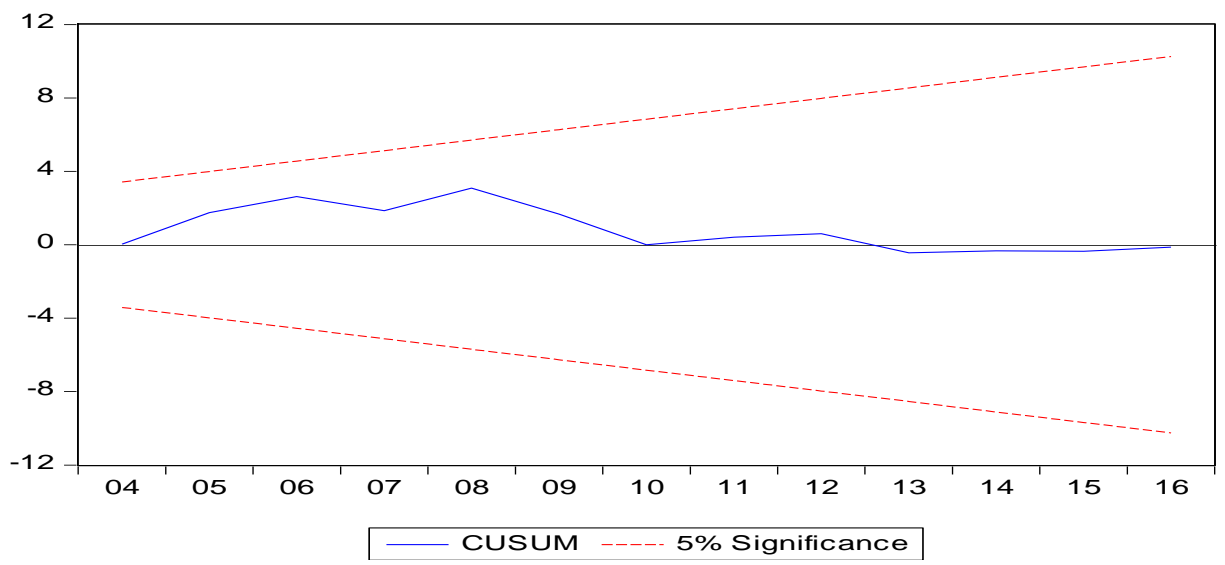

Figure 4: CUSUM Stability Test Results

\section{Conclusion}

The study analyzed the short and long-run relationship between selected macroeconomic variables namely exports, GDP per capita, exchange rate, inflation, gross capital formation and fiscal deficit for Pakistan over the period 1985 to 2016. Augmented Dickey-Fuller (ADF) test was applied to the data for checking the stationarity in data. The ADF the results showed that all the variables were stationary at first difference. Knowing the data was stationary at I (1), Johansen Co-integration test and Vector Error Correction Method were used for investigation the long run relationship between dependent and independent variables. Finally, the existence of short-run relationship was checked by using the Wald test. The results showed that exports, exchange rate, GDP per capita, inflation, gross capital formation are the most important determinant of fiscal deficit in Pakistan. This study concluded that Exports, GDP per capita and inflation has a high impact on fiscal deficit in Pakistan. 


\section{References}

Agenor, R, P., \& Montiel, J. P. (1999), Development macro-economics, Princeton University Press, 2nd edition.

Agha, A. I., \& Khan, M. S. (2006). An empirical analysis of fiscal imbalances and inflation in Pakistan. SBP Research Bulletin2(2).

Anwar, M., \& Ahmad, M. (2012). Political determinants of budget deficit in Pakistan: An empirical investigation (No. 135). HWWI Research Paper.

Brima, S., \& Pearce, E. (2015). Budget deficit and macroeconomic variables in Sierra leone: an econometric approach. Journal of Economics and Sustainable Development, 6(4)

Chaudhary, M. A., \& Abe, K. (1999), Pakistan economy: Current situation and future prospects. Chiba University Economic Journal, 14(1),49-85.

Epaphra, M. (2017). Analysis of budget deficits and macroeconomic fundamentals: A VARVECM approach. Journal of Economics \& Management, 30, 0-57

Government of Pakistan (2016/2017). Pakistan Economic Survey http://www.finance.gov.pk

Jagirani, T., Abro, k., \&Tahir, H. (2016). A vector error correction model (VECM): An approach to short-run and long-run causality between solvency and liquidity: a study of oil \& gas development company limited (OGDCL), Pakistan. International Journal of Management Sciences and Business Research, 5(4).

Javid, A., Arif, U., \& Arif, A. (2011). Economic, political and institutional determinants of budget deficits volatility in selected Asian countries. The Pakistan Development Review 50(4), 649-662.

Juseoff, K., Shamsudin, N., Mohamad, Z., Jusoh. N., Baharuddin, N. S., \& Asari, H. (2011), A vector error correction model (VECM) approach in explaining the relationship between interest rate and inflation towards exchange rate volatility in Malaysia, World Applied Sciences Journal, 49-56.

Peacock, A. T. (1961). and J. Wiseman. The Growth of Public Expenditure in the United Kingdom.

Romer, C. (1986). Spurious volatility in historical unemployment data. Journal of Political Economy, 94(1), 1-37.

Safdar, F., \& Padda,I. (2017). Impact of institutions on budget deficit: the case of Pakistan. NUML International Journal of Business \& Management. 12(1),2410-5392. 
Torayeh, N. M. (2015). Fiscal deficits in Egypt: is it a macroeconomic or politicoinstitutional problem? The Journal of Developing Areas, 49(1),365-380.

Uppal, J. (2011). Government budget deficits and the development of the bond market in Pakistan: issues and challenges. The Lahore Journal of Economics 16.159-198

Usman, O. A., \& Adebisi, D. G. (2017). A structural break analysis of fiscal deficit process in Nigeria. The Review of Black Political Economy, 44(3-4), 341-352.

Wiseman, J., Peacock, A. T., \& Veverka, J. (1961). The Growth of Public Expenditure in the United Kingdom. Princeton UP.

World bank indicator (2016). https://data.worldbank.org. 